\title{
Theoretical Study of InAlN/GaN High Electron Mobility Transistor (HEMT) with a Polarization-Graded AlGaN Back-Barrier Layer
}

\author{
Yan Gu ${ }^{1,3}$, Dongmei Chang ${ }^{2}$, Haiyan Sun ${ }^{1, *}$, Jicong Zhao ${ }^{1}$, Guofeng Yang ${ }^{3}{ }^{\mathbb{C}}$, Zhicheng Dai ${ }^{1}$ \\ and Yu Ding ${ }^{1}$ \\ 1 School of Information Science and Technology, Nantong University, Nantong 226019, China \\ 2 Department of Public Course Teaching, Shandong Polytechnic College, Jining 272067, China \\ 3 School of Science, Jiangsu Provincial Research Center of Light Industrial Optoelectronic \\ Engineering and Technology, Jiangnan University, Wuxi 214122, China \\ * Correspondence: sun.yan@ntu.edu.cn; Tel.: +86-513-85012700
}

Received: 18 July 2019; Accepted: 6 August 2019; Published: 10 August 2019

Abstract: An inserted novel polarization-graded AlGaN back barrier structure is designed to enhance performances of $\mathrm{In}_{0.17} \mathrm{Al}_{0.83} \mathrm{~N} / \mathrm{GaN}$ high electron mobility transistor (HEMT), which is investigated by the two-dimensional drift-diffusion simulations. The results indicate that carrier confinement of the graded AlGaN back-barrier HEMT is significantly improved due to the conduction band discontinuity of about $0.46 \mathrm{eV}$ at interface of $\mathrm{GaN} / \mathrm{AlGaN}$ heterojunction. Meanwhile, the two-dimensional electron gas (2DEG) concentration of parasitic electron channel can be reduced by a gradient $\mathrm{Al}$ composition that leads to the complete lattice relaxation without piezoelectric polarization, which is compared with the conventional $\mathrm{Al}_{0.1} \mathrm{Ga}_{0.9} \mathrm{~N}$ back-barrier HEMT. Furthermore, compared to the conventional back-barrier HEMT with a fixed Al-content, a higher transconductance, a higher current and a better radio-frequency performance can be created by a graded $\mathrm{AlGaN}$ back barrier.

Keywords: $\mathrm{In}_{0.17} \mathrm{Al}_{0.83} \mathrm{~N} / \mathrm{GaN}$ HEMT; graded-polarization; back barrier; parasitic electron channel; electron confinement

\section{Introduction}

Over the years, gallium nitride $(\mathrm{GaN})$ which is a typical representative of third-generation wide bandgap semiconductor materials, has attracted enormous interest due to it having a high critical electric field, electron gas owing to polarization, higher electron mobility and saturation velocity [1-3]. Therefore, the GaN-based high electron mobility transistors (HEMTs) allows us to achieve higher breakdown voltage, lower on-resistance and high operation switching frequency [4-6]. Considering the reliability problems of AlGaN/GaN HEMTs, which are caused by lattice defects due to lattice mismatch and piezoelectric effect at the AlGaN/GaN heterojunctions [7-9], an AlInN barrier layer has attractively replaced a commonly applied AlGaN barrier layer to improve performances of GaN-based HEMTs. The $\mathrm{In}_{\mathrm{x}} \mathrm{Al}_{1-\mathrm{x}} \mathrm{N}$ is lattice matched to $\mathrm{GaN}$ when the $\mathrm{Al}$ composition of $\operatorname{In}_{\mathrm{x}} \mathrm{Al}_{1-\mathrm{x}} \mathrm{N}$ is 0.83 [10]. Thus, a significantly higher two-dimensional electron gas (2DEG) density can be induced by spontaneous polarization at $\mathrm{In}_{0.17} \mathrm{Al}_{0.83} \mathrm{~N} / \mathrm{GaN}$ interface and the HEMT's reliability can be enhanced [6,11-14]. An additional thin AlN interlayer is set between the AlInN barrier layer and the GaN channel layer to further improve performances of the $\operatorname{In}_{0.17} \mathrm{Al}_{0.83} \mathrm{~N} / \mathrm{GaN}$ HEMT. The AlN can increase discontinuity of the conduction band at heterojunction interface due to its larger forbidden band width, which plays a dominant factor for the significant increase of 2DEG concentration [15]. In addition, the AlN in $\operatorname{In}_{0.17} \mathrm{Al}_{0.83} \mathrm{~N} / \mathrm{GaN}$ heterojunction interface can reduce the alloy scattering which increases the mobility of the device [16]. Although the proposed InAlN/AlN/GaN structure has the stated advantages, part 
of the 2DEG will spill from the channel into the buffer layer, resulting in the reduction of mobility and reliability. It can be explained that $\mathrm{GaN}$ is both a buffer layer and a channel layer in a single heterojunction structure [17]. The most direct way to enhance the confinement of heterojunction 2DEG and suppress the overflow of carriers into the buffer layer is to use a back barrier, which constitutes a double heterojunction structure. Recently, many researches have reported on effects of the AlGaN back-barrier layers on the HEMTs with the double heterojunction structures [18-21]. To some extent, it can enhance carrier confinement but also produce an unwanted parasitic channel at the AlGaN back-barrier/GaN buffer interface. According to our previous works [22,23], the graded AlGaN back-barrier with $\mathrm{Al}$ content changing linearly from 0 to 0.1 can weaken the polarization between $\mathrm{AlGaN}$ and $\mathrm{GaN}$ buffer layer, and reduce the adverse effect of parasitic channel.

In this work, we propose a conventional $\operatorname{In}_{0.17} \mathrm{Al}_{0.83} \mathrm{~N} / \mathrm{AlN} / \mathrm{GaN}$ structure with a $25 \mathrm{~nm}$-thick $\mathrm{Al}_{0.1} \mathrm{Ga}_{0.9} \mathrm{~N}$ back-barrier layer that can improve confinement of the channel, but a parasitic channel would be generated at the $\mathrm{Al}_{0.1} \mathrm{Ga}_{0.9} \mathrm{~N}$ barrier/GaN buffer interface. Therefore, a polarization-graded AlGaN back barrier replaces the $\mathrm{Al}_{0.1} \mathrm{Ga}_{0.9} \mathrm{~N}$ back barrier to reduce the harm of parasitic channel. The $\mathrm{Al}$ composition of graded $\mathrm{AlGaN}$ back-barrier layer near the side of $\mathrm{GaN}$ main channel is 0.1 , and gradually reduces to 0 far away from the main channel. Numerical simulations can support the design of non-conventional devices in a short time, and a large amount of works on devices have been investigated by Atlas-Silvaco physical simulation [24-29]. The electron distributions and the conduction band profiles of HEMTs with an $\mathrm{Al}_{0.1} \mathrm{Ga}_{0.9} \mathrm{~N}$ back-barrier and a graded back-barrier are calculated by Atlas-Silvaco physical simulator. The influences of two structures on performances of the HEMTs are compared theoretically. The results indicate that confinement of 2DEG can be effectively enhanced by a polarization-graded back barrier. In addition, the electron concentration in the parasitic channels can be weakened by the AlGaN back barrier layer with a gradient of polarization. It is beneficial for the improvement of transconductance, drain current, current gain cut-off frequency and power gain cut-off frequency, compared with the conventional $\mathrm{Al}_{0.1} \mathrm{Ga}_{0.9} \mathrm{~N}$ back-barrier HEMT.

\section{Device Description and Physical Models}

Figure 1a,b shows the schematic cross-sectional diagram of the designed conventional HEMTs with an $\mathrm{Al}_{0.1} \mathrm{Ga}_{0.9} \mathrm{~N}$ back barrier and a polarization-graded $\mathrm{AlGaN}$ back barrier. The epitaxial structure of an $\mathrm{Al}_{0.1} \mathrm{Ga}_{0.9} \mathrm{~N}$ back-barrier HEMT was composed of a $2 \mu \mathrm{m}$ unintentionally n-type doped $\mathrm{GaN}$ buffer layer, with a background carrier concentration of $1 \times 10^{16} \mathrm{~cm}^{-3}$ [30], a $1 \mathrm{~nm}$ AlN space layer, a $10 \mathrm{~nm}$ undoped $\mathrm{In}_{0.17} \mathrm{Al}_{0.83} \mathrm{~N}$ barrier layer, a 14-nm-thick GaN channel and a $25 \mathrm{~nm}$ undoped $\mathrm{Al}_{0.1} \mathrm{Ga}_{0.9} \mathrm{~N}$ back-barrier layer. Compared with the conventional back-barrier structure, the optimized structure introduced a $25 \mathrm{~nm}$ graded $\mathrm{AlGaN}$ back barrier with $\mathrm{Al}$ content linearly changing from $0 \%$ (bottom) to 10\% (top) along the epitaxial growth. In both structures, Ohmic contacts were formed in the source and drain terminals. The distance of gate-source, gate-drain, and length of gate were $0.5 \mu \mathrm{m}, 10 \mu \mathrm{m}$, and $2 \mu \mathrm{m}$, respectively. The device surface was passivated by using $\mathrm{Si}_{3} \mathrm{~N}_{4}$ thin film to reduce the current collapse effect in the HEMT [31]. For all the simulations, donor trap was introduced at the $\operatorname{In}_{0.17} \mathrm{Al}_{0.83} \mathrm{~N}$ with a trap level of $0.42 \mathrm{eV}$ and a density of $3.86 \times 10^{13} \mathrm{~cm}^{-3}$ [32], while acceptor trap was considered in the unintentional doped (UID) GaN buffer with a trap level of $0.4 \mathrm{eV}$ below the conduction band and a trap density of $1 \times 10^{17} \mathrm{~cm}^{-3}$. 


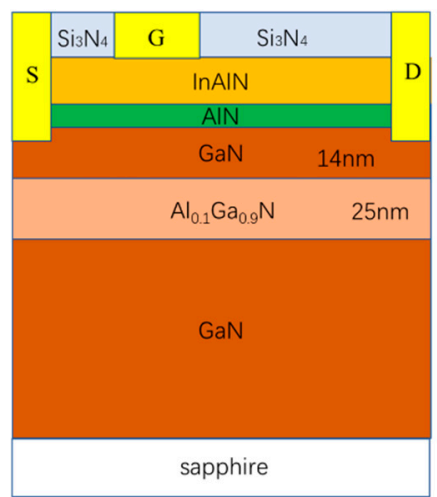

(a)

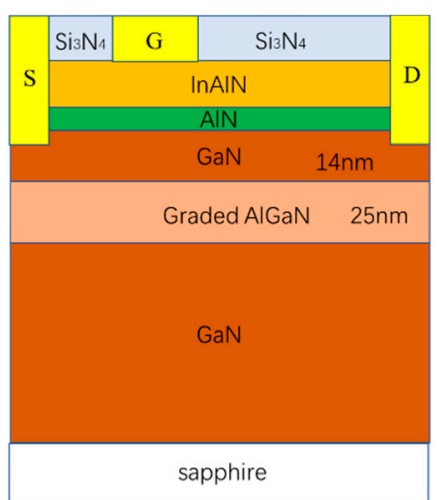

(b)

Figure 1. Schematic diagram of the designed lattice-matched $\operatorname{In}_{0.17} \mathrm{Al}_{0.83} \mathrm{~N} / \mathrm{GaN}$ high electron mobility transistor (HEMT) structure (a) with an $\mathrm{Al}_{0.1} \mathrm{Ga}_{0.9} \mathrm{~N}$ back barrier and (b) with a graded $\mathrm{AlGaN}$ back barrier.

During the two-dimensional numerical calculation, the drift-diffusion transport model as well as several important physical models such as Fermi-Dirac, low field electron mobility, high field mobility, Shockley-Read-Hall (SRH) and polarization were used to simulate the device response. The physical parameters of $\mathrm{GaN}, \mathrm{AlN}, \mathrm{Al}_{0.1} \mathrm{Ga}_{0.9} \mathrm{~N}$ and $\mathrm{In}_{0.17} \mathrm{Al}_{0.83} \mathrm{~N}$ during the simulation are shown in Table 1 [33-36].

Table 1. Parameters of $\mathrm{GaN}, \mathrm{AlN}, \mathrm{Al}_{0.83} \mathrm{In}_{0.1} 7 \mathrm{~N}, \mathrm{Al}_{0.1} \mathrm{Ga}_{0.9} \mathrm{~N}$ in the simulation.

\begin{tabular}{ccccc}
\hline Parameter & GaN & AlN & $\mathbf{A l}_{\mathbf{0}_{\mathbf{0 . 3}} \mathbf{I n}_{\mathbf{0 . 1 7}} \mathbf{N}}$ & $\mathbf{A l}_{\mathbf{0 . 1}} \mathbf{G a}_{\mathbf{0 . 9}} \mathbf{N}$ \\
\hline Band gap $(\mathrm{eV})$ & 3.42 & 6.15 & 4.62 & 3.58 \\
Permittivity & 10.28 & 10.31 & 11.04 & 10.28 \\
Hole mobility $\left(\mathrm{cm}^{2} / \mathrm{Vs}\right)$ & 22 & 14 & 82 & - \\
Saturated velocities $\left(v_{\text {sat }}\right)$ for & 2.0 & 2.17 & 1.1 & - \\
$\quad \begin{array}{c}\text { electrons }\left(10^{7} \mathrm{~cm} / \mathrm{s}\right) \\
\text { Spontaneous polarization, }\end{array}$ & -0.034 & -0.090 & -0.072 & -0.038 \\
$P_{s p}\left(\mathrm{C} / \mathrm{m}^{2}\right)$ & & & \\
\hline
\end{tabular}

The two mobility models have been used to consider various types of scattering mechanisms [37]. The low field mobility model can be given by [34]:

$$
\begin{gathered}
\frac{1}{u(N, T)}=a\left(\frac{N}{1 \times 10^{17}}\right)\left(\frac{T}{300}\right)^{\frac{-3}{2}} \times \ln \left[1+3\left(\frac{T}{300}\right)^{2}\left(\frac{N}{1 \times 10^{17}}\right)^{\frac{-2}{3}}\right] \\
+b\left(\frac{T}{300}\right)^{\frac{3}{2}}+\frac{c}{\exp \left(\frac{1065}{T}\right)-1}
\end{gathered}
$$

where $a=2.61 \times 10^{-4} / \mathrm{V} \cdot \mathrm{s} \cdot \mathrm{cm}^{-2}, b=9.8 \times 10^{-4} / \mathrm{V} \cdot \mathrm{cm}^{-2}$ and $c=1.7 \times 10^{-2} / \mathrm{V} \cdot \mathrm{s} \cdot \mathrm{cm}^{-2} \cdot u(N, T)$ is the mobility as a function of doping and ambient temperature, $N$ is the total doping concentration, and $T$ is the ambient temperature.

The high field mobility model can be specified as below [38]:

$$
u(E)=\frac{u(N, T)+v_{s a t} \frac{E^{\left(N_{1}-1\right)}}{E_{c}^{N_{1}}}}{1+a_{n}\left(\frac{E}{E_{c}}\right)^{N_{2}}+\left(\frac{E}{E_{c}}\right)^{N_{1}}},
$$

where $u(N, T)$ is the low field mobility, $v_{\text {sat }}$ is saturation velocities, and $E$ is the electric field. The values of $E_{c}, a_{n}, N_{1}$, and $N_{2}$ can be referred to [38].

SRH and Fermi-Dirac statistics are also considered. SRH recombination occurs when an electron gets trapped, referring to a trap-assisted recombination process. In order to investigate the specific 
physical mechanism of electron trapping, electron trapping process of each trap level should be calculated in the SRH recombination model. The rate of electron trapping [38-41] is given by

$$
R_{n e t}^{S R H}=\frac{p n-n_{i e}{ }^{2}}{\tau_{p}\left[n+n_{i e} \exp \left(\frac{E_{\text {trap }}}{k T}\right)\right]+\tau_{n}\left[p+n_{i e} \exp \left(\frac{-E_{\text {trap }}}{k T}\right)\right]},
$$

where $E_{\text {trap }}$ is the difference between the trap energy level and intrinsic Fermi level, $n_{i e}$ is intrinsic carrier concentration, and $T$ is the lattice temperature. $\tau_{n}$ and $\tau_{p}$ are the lifetimes of electrons and holes, respectively, both of which are assumed to be $10^{-9} \mathrm{~s}$.

Polarization modeling is critical for GaN based devices. Here, $P_{P E}$ and $P_{S P}$ represent the piezoelectric polarization and spontaneous polarization, respectively. The total polarization-induced polarization charge density is defined as [35]:

$$
P_{\text {total }}=\left[P_{P E}(\text { bottom })+P_{S P}(\text { bottom })\right]-\left[P_{P E}(\text { top })+P_{S P}(\text { top })\right]
$$

Since $\operatorname{In}_{0.17} \mathrm{Al}_{0.83} \mathrm{~N} / \mathrm{GaN}$ is lattice-matched and the graded back barrier layer is assumed as complete lattice relaxation, the sum of polarization in the device is spontaneous polarization without any piezoelectric polarization. A space polarization-induced charge would be generated by a gradient of polarization of the $\mathrm{Al}_{x} \mathrm{Ga}_{1-x} \mathrm{~N}$ back barrier which varies along the growth direction. The corresponding density is given by $[42,43]$ :

$$
\rho P=-\nabla \cdot P=-\frac{\partial P}{\partial Z}
$$

With

$$
P=P_{s p}\left(A l_{x} G a_{1-x} N\right)=x P_{s p}(A l N)+(1-x) P_{s p}(G a N) .
$$

\section{Results and Discussion}

The conduction band diagrams of two different structures with back barrier under zero bias voltage calculated by two-dimensional self-consistent simulations are shown in Figure 2. The conduction band diagram of a conventional HEMT was simulated to observe the conduction band discontinuity caused by a back-barrier layer. It is obvious that the back barrier can raise the conduction band edge of the side of the potential well and enhance confinement of the heterojunction 2DEG. Comparing with the HEMT with a single heterojunction structure, the conduction band edge of the potential well of the device with an $\mathrm{Al}_{0.1} \mathrm{Ga}_{0.9} \mathrm{~N}$ back barrier is increased by $0.69 \mathrm{eV}$, while the structure with an Al-graded back barrier is increased by $0.46 \mathrm{eV}$. Furthermore, the depth of electron potential well of the parasitic electron channel at interface of $\mathrm{AlGaN} / \mathrm{GaN}$ in the polarization-graded AlGaN back-barrier HEMT is shallower than that of the device with an $\mathrm{Al}_{0.1} \mathrm{Ga}_{0.9} \mathrm{~N}$ back barrier. The results are attributed to a gradient of polarization of $\mathrm{AlGaN}$, which results in the complete lattice relaxation in the graded AlGaN back barrier without any piezoelectric polarization.

Figure 3 shows the carrier distributions of the three different structures, it is evident that at the AlN/GaN interface generates the primary quantum well. The electron concentration of the conventional HEMT, graded back-barrier HEMT and back-barrier HEMT were about $11 \times 10^{19} \mathrm{~cm}^{-3}$, $8.81 \times 10^{19} \mathrm{~cm}^{-3}$, and $8.8 \times 10^{19} \mathrm{~cm}^{-3}$, respectively. Moreover, a shallower secondary quantum well was also produced at the interface between the AlGaN layer and the GaN buffer layer, demonstrating the formation of a conductive parasitic channel. It is obvious from the inset of Figure 3 that the 2DEG concentration of secondary quantum well in the graded AlGaN back-barrier HEMT was about $0.1 \times 10^{19} \mathrm{~cm}^{-3}$, lower than that of the secondary quantum well in the AlGaN back-barrier HEMT with 2DEG concentration of $0.2 \times 10^{19} \mathrm{~cm}^{-3}$. Compared to the HEMT with a single heterojunction, the electron distribution of the main channel was narrowed due to a back-barrier layer, while the carrier distribution of the structure with a fixed Al-composition back barrier layer was narrower than that of the structure with a graded Al-composition back-barrier layer. In other words, the structure 
with a graded Al-composition contributes to the improved confinement of 2DEG and the weakening of the generation of parasitic channels.

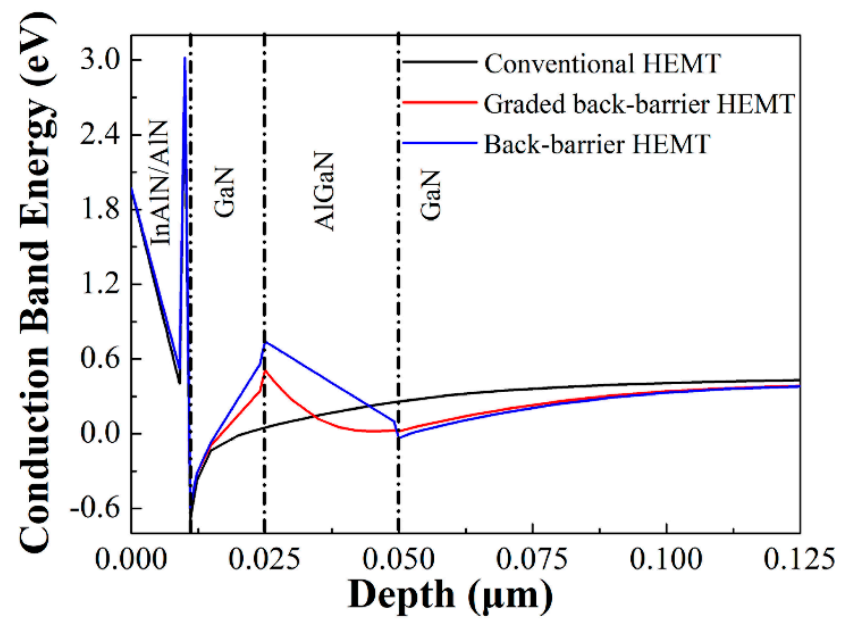

Figure 2. The conduction band diagrams of the $\mathrm{In}_{0.17} \mathrm{Al}_{0.83} \mathrm{~N} / \mathrm{AlN} / \mathrm{GaN}$ HEMT, HEMTs with graded back-barrier layer and $\mathrm{Al}_{0.1} \mathrm{Ga}_{0.9} \mathrm{~N}$ back-barrier layer under zero applied voltage.

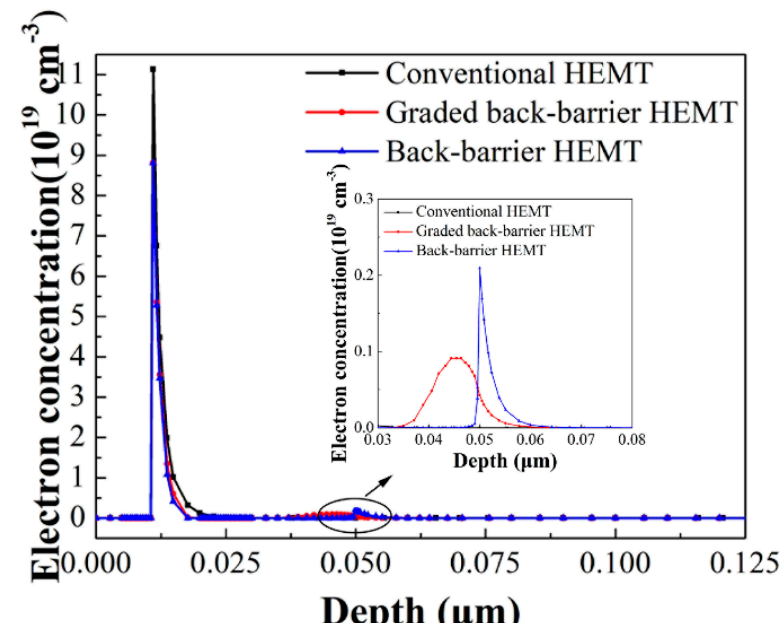

Figure 3. The electron concentration distributions of the $\operatorname{In}_{0.17} \mathrm{Al}_{0.83} \mathrm{~N} / \mathrm{AlN} / \mathrm{GaN}$ HEMT, the graded back-barrier HEMT and the $\mathrm{Al}_{0.1} \mathrm{Ga}_{0.9} \mathrm{~N}$ back-barrier HEMT. The inset shows the electron concentration in the parasitic channel at $\mathrm{Al}_{\mathrm{x}} \mathrm{Ga}_{1-\mathrm{x}} \mathrm{N} / \mathrm{GaN}$ interface.

Figure 4 specifically illustrates the two-dimensional contour map of the electron distribution inside the two HEMTs with different structure. Figure 4a,b corresponds to the polarization-graded AlGaN back-barrier HEMT and the $\mathrm{Al}_{0.1} \mathrm{Ga}_{0.9} \mathrm{~N}$ back-barrier HEMT, respectively. It can be seen that the electron concentration at the AlN/GaN interface was the highest, and formed a 2DEG potential well, which is consistent with the results shown in Figures 2 and 3. Figure $4 a, b$ shows that the enhanced 2DEG confinement was obtained by introducing a back-barrier layer due to the creation of an obvious conduction band discontinuity. The electron concentration at $25 \mathrm{~nm}(\mathrm{GaN} / \mathrm{AlGaN})$ shown in Figure 4a is higher than that in Figure $4 \mathrm{~b}$, while that at the $50 \mathrm{~nm}(\mathrm{AlGaN} / \mathrm{GaN})$ is lower than Figure $4 \mathrm{~b}$. This is because the gradual change of the $\mathrm{Al}$ composition in $\mathrm{AlGaN}$ back barrier weakened the polarization effect between AlGaN back-barrier layer and GaN buffer layer. 

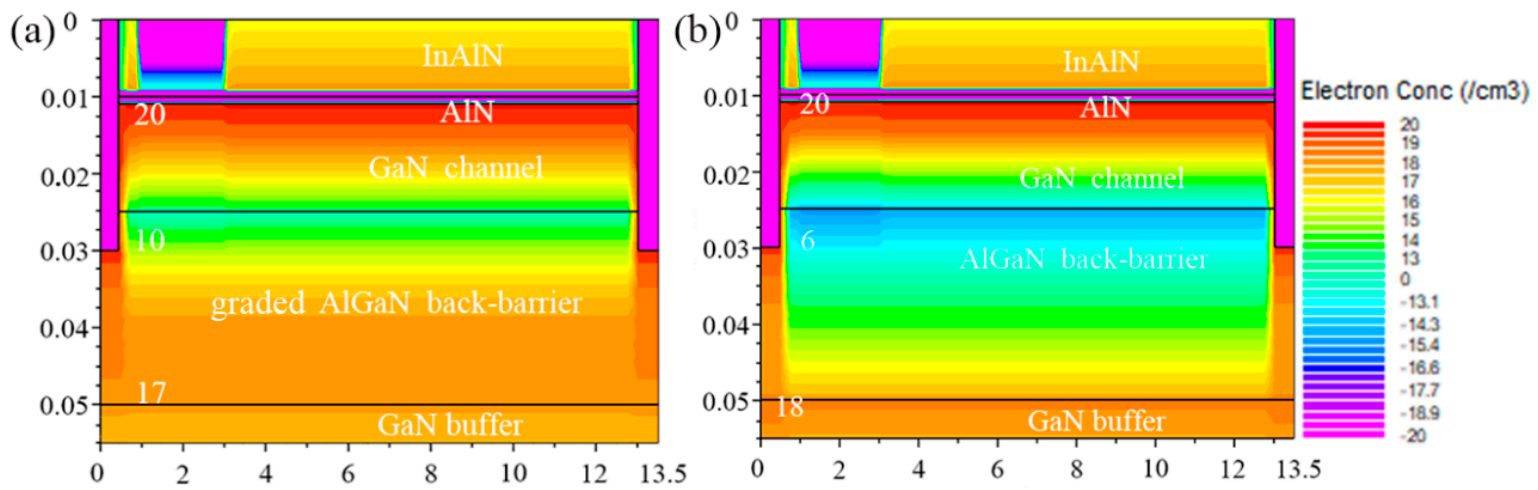

Figure 4. Structure chromaticity plots of the electron concentration distributions inside the two different HEMT structures with (a) a graded $\mathrm{AlGaN}$ back barrier and (b) an $\mathrm{Al}_{0.1} \mathrm{Ga}_{0.9} \mathrm{~N}$ back barrier.

Figure 5 displays the transfer characteristics of the two different structures at $\mathrm{V}_{\mathrm{ds}}=5 \mathrm{~V}$. It was found that the maximum saturation current and transconductance of the graded back-barrier HEMT can be increased compared with that of the $\mathrm{Al}_{0.1} \mathrm{Ga}_{0.9} \mathrm{~N}$ back-barrier HEMT. Figure $5 \mathrm{a}$ shows the curves of $\mathrm{V}_{\mathrm{g}}-\mathrm{I}_{\mathrm{d}}$ (the threshold voltages are about $-4.5 \mathrm{~V}$ and $-4 \mathrm{~V}$ ) corresponding to the graded back-barrier HEMT and the $\mathrm{Al}_{0.1} \mathrm{Ga}_{0.9} \mathrm{~N}$ back-barrier HEMT, respectively, which shifted negatively. The reason is that the back-barrier layer generates a negatively polarization field and then the 2DEG are confined in a narrower potential well. In addition, the threshold voltage negatively shifts about $0.5 \mathrm{~V}$ due to attenuation of the negatively polarization field in the polarization-graded AlGaN back barrier and weaker confinement of carriers in the main channel, compared with that of the $\mathrm{Al}_{0.1} \mathrm{Ga}_{0.9} \mathrm{~N}$ back-barrier HEMT. The variations in $G_{m}$ with $V_{g}$ for two devices are depicted in Figure $5 b$. The structure with a graded back barrier shows the $G_{m}$ peak value of $304 \mathrm{mS} / \mathrm{mm}$ at $V_{g s}=-1.75 \mathrm{~V}$, which is higher than that of the structure with an $\mathrm{Al}_{0.1} \mathrm{Ga}_{0.9} \mathrm{~N}$ back-barrier $\left(295 \mathrm{mS} / \mathrm{mm}\right.$ at $\left.\mathrm{V}_{\mathrm{gs}}=-1.5 \mathrm{~V}\right)$, indicating that an improved control of drain current by the gate voltage was obtained in the polarization-graded one. The increase in the peak transconductance results from the fact that the gradual $\mathrm{Al}$ composition can weaken the effect of the parasitic channel on the main channel and increase the mobility of the 2DEG.
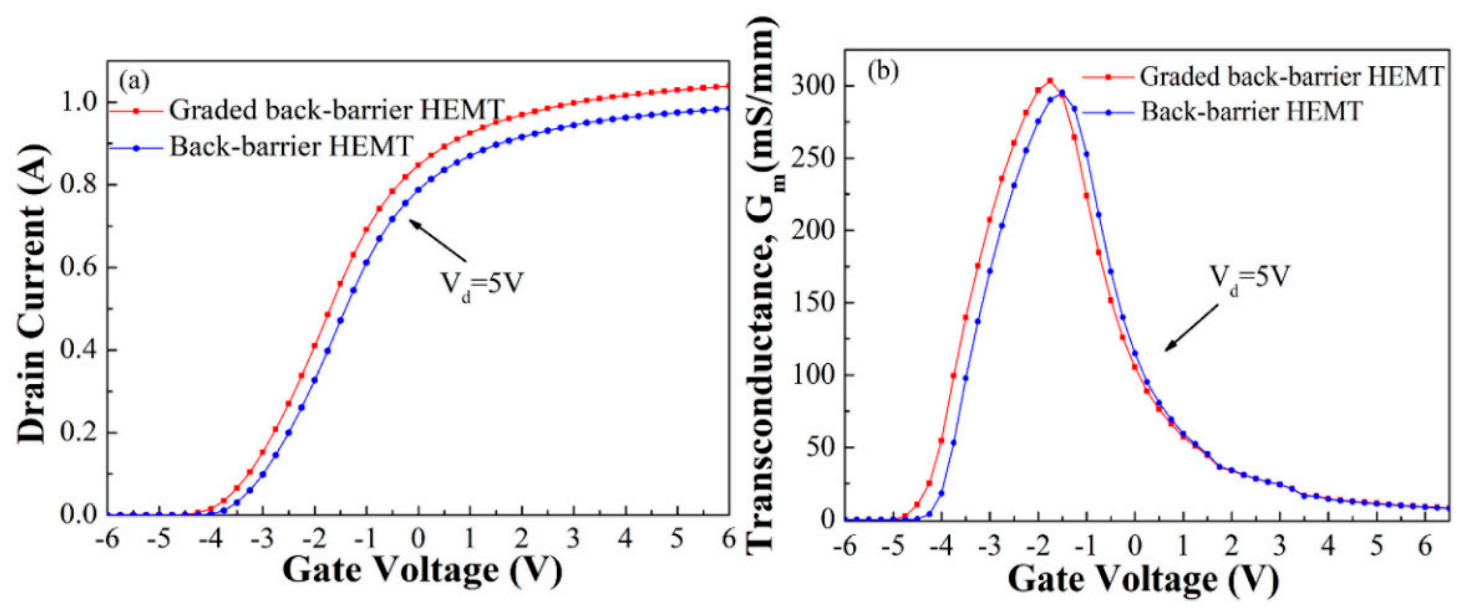

Figure 5. Calculated (a) gate voltage-drain current $\left(\mathrm{V}_{\mathrm{g}}-\mathrm{I}_{\mathrm{d}}\right)$ and (b) gate voltage-transconductance $\left(\mathrm{V}_{\mathrm{g}}-\mathrm{G}_{\mathrm{m}}\right)$ transfer characteristics at drain voltage of $5 \mathrm{~V}$ for the HEMTs with a grade back barrier and an AlGaN back barrier.

Figure 6 represents the current-voltage $\left(\mathrm{I}_{\mathrm{d}}-\mathrm{V}_{\mathrm{d}}\right)$ output characteristics at $\mathrm{V}_{\mathrm{g}}$ from $0 \mathrm{~V}$ to $-5 \mathrm{~V}$ for the two devices. The density of the maximum drain saturation current of $1.25 \mathrm{~mA} / \mathrm{mm}$ was obtained at $\mathrm{V}_{\mathrm{gs}}=0 \mathrm{~V}$ in a graded back-barrier HEMT, which was about $13.6 \%$ higher than that of the $\mathrm{Al}_{0.1} \mathrm{Ga}_{0.9} \mathrm{~N}$ back-barrier HEMT $\left(1.1 \mathrm{~mA} / \mathrm{mm}\right.$ at $\left.\mathrm{V}_{\mathrm{gs}}=0 \mathrm{~V}\right)$. The larger drain current in a graded back-barrier HEMT 
was mainly due to the lower threshold voltage shown in Figure $5 a$, while the concentrations of electron in the graded back-barrier HEMT and the conventional $\mathrm{Al}_{0.1} \mathrm{Ga}_{0.9} \mathrm{~N}$ back-barrier HEMT were nearly the same.

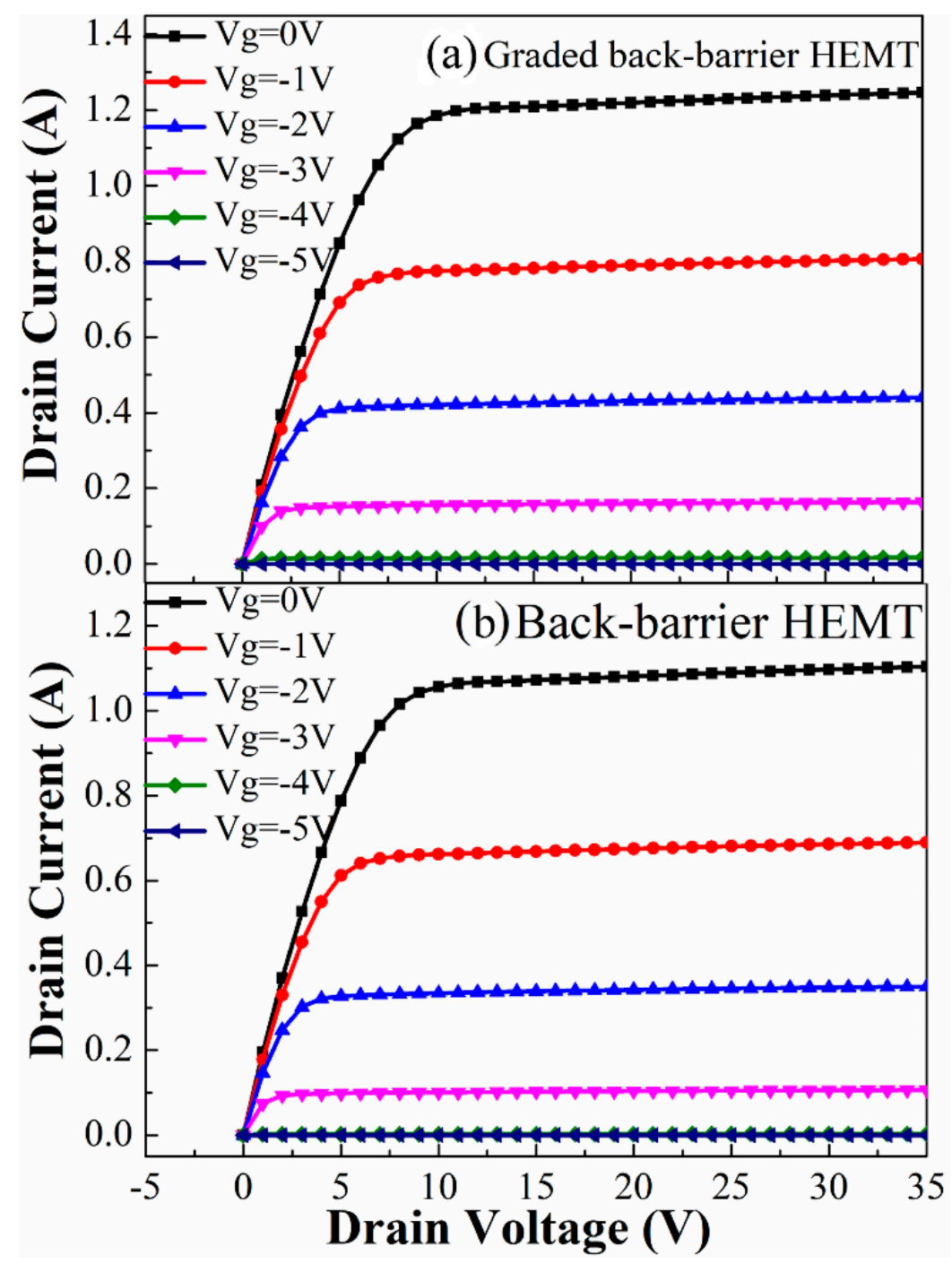

Figure 6. The drain voltage-drain current $\left(\mathrm{V}_{\mathrm{d}}-\mathrm{I}_{\mathrm{d}}\right)$ output characteristics at gate voltage from $0 \mathrm{~V}$ to $-5 \mathrm{~V}$ for the two HEMT structures with (a) a graded AlGaN back barrier and (b) an $\mathrm{Al}_{0.1} \mathrm{Ga}_{0.9} \mathrm{~N}$ back barrier.

Based on the small-signal AC simulation, the frequency characteristics of the devices are discussed. The variations in the $\mathrm{f}_{\max }$ and $\mathrm{f}_{\mathrm{T}}$ regarding to the change of gate voltage for the two HEMTs are shown in Figure 7. It can be seen that the RF performance was improved by a gradual Al-composition in the AlGaN back barrier. The device with a graded back barrier achieved a peak value of current gain cutoff frequency of $5 \mathrm{GHz}$ and a peak value of power gain cutoff frequency of $19 \mathrm{GHz}$, which were both higher than that of the conventional one. The reasons for this result are mainly due to the higher transconductance and the higher output resistance resulting from a graded polarization in the AlGaN back barrier. 


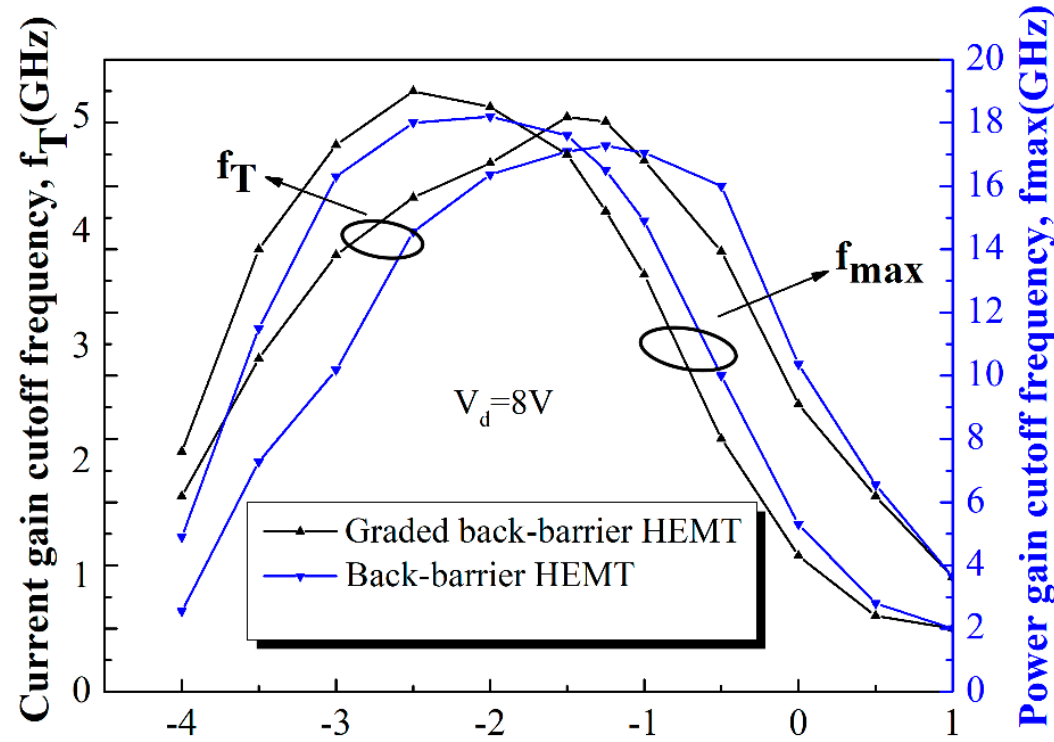

Gate Voltage(V)

Figure 7. Simulated radio-frequency (RF) performance of the two devices at $8 \mathrm{~V}$ drain voltage.

\section{Conclusions}

In summary, a lattice-matched $\operatorname{In}_{0.17} \mathrm{Al}_{0.83} \mathrm{~N} / \mathrm{AlN} / \mathrm{GaN}$ HEMT with a polarization-graded AlGaN back barrier is proposed by two-dimensional analysis of Atlas drift-diffusion simulations. The improved performance of the graded back-barrier HEMT is systematically demonstrated by comparing to the HEMT with an AlGaN back barrier. The electron confinement in the channel is enhanced effectively by introducing a back barrier, resulting in the improved performance of the device. In addition, a gradient of polarization in the back barrier can reduce the 2DEG concentration in the parasitic channel and weaken adverse effect of the channel, which is beneficial to improve the electronic performance of the device. As a result, a polarization-graded AlGaN back barrier can be an alternative to a fixed Al-content $\mathrm{Al}_{x} \mathrm{Ga}_{1-\mathrm{x}} \mathrm{N}$ back barrier design to obtain a high-performance InAlN/GaN HEMTs.

Author Contributions: Conception and design of study: Y.G., H.S.; acquisition of data: D.C., J.Z.; analysis and /or interpretation of data: G.Y., Z.D., Y.D.; drafting the manuscript: Y.G.; revising the manuscript: J.Z., G.Y.; approval of the version of the manuscript to be published: H.S.

Funding: This research was funded by the National Natural Science Foundation of China (Nos. 61804084, 11604124).

Acknowledgments: The authors would like to thank editors and anonymous reviewers for their special effort.

Conflicts of Interest: The authors declare no conflict of interest.

\section{References}

1. Mishra, U.K.; Parikh, P.; Wu, Y.F. AlGaN/GaN HEMTs-an overview of device operation and applications. Proc. IEEE 2002, 90, 1022-1031. [CrossRef]

2. Mishra, U.K.; Shen, L.; Kazior, T.E.; Wu, Y.F. GaN-based RF power devices and amplifiers. Proc. IEEE 2008, 96, 287-305. [CrossRef]

3. Frayssinet, E.; Knap, W.; Lorenzini, P.; Grandjean, N.; Massies, J.; Skierbiszewski, C.; Suski, T. High electron mobility in AlGaN/GaN heterostructures grown on bulk GaN substrates. Appl. Phys. Lett. 2000, 77, 2551-2553. [CrossRef]

4. Visalli, D.; Van Hove, M.; Derluyn, J.; Degroote, S.; Leys, M.; Cheng, K.; Germain, M.; Borghs, G. AlGaN/GaN/AlGaN double heterostructures on silicon substrates for high breakdown voltage field-effect transistors with low on-resistance. Jpn. J. Appl. Phys. 2009, 48, 04C101. [CrossRef]

5. Kuzuhara, M.; Tokuda, H. Low-loss and high-voltage III-nitride transistors for power switching applications. IEEE Trans. Electron Devices 2015, 62, 405-413. [CrossRef] 
6. Kuzmik, J. Power electronics on InAlN/(In) GaN: Prospect for a record performance. IEEE Electron Devices Lett. 2001, 22, 510-512. [CrossRef]

7. Feng, Z.H.; Zhou, Y.G.; Cai, S.J.; Lau, K.M. Enhanced thermal stability of the two-dimensional electron gas in $\mathrm{GaN} / \mathrm{AlGaN} / \mathrm{GaN}$ heterostructures by $\mathrm{Si}_{3} \mathrm{~N}_{4}$ surface-passivation-induced strain solidification. Appl. Phys. Lett. 2004, 85, 5248-5250. [CrossRef]

8. Joh, J.; Alamo, J.D. Impact of electrical degradation on trapping characteristics of GaN HEMTs. In Proceedings of the 2008 IEEE International Electron Devices Meeting, San Francisco, CA, USA, 15-17 December 2008.

9. Lin, Z.; Kim, H.; Lee, J. Thermal stability of Schottky contacts on strained AlGaN/GaN heterostructures. Appl. Phys. Lett. 2004, 84, 1585-1587. [CrossRef]

10. Neuburger, M.; Zimmermann, T.; Kohn, E.; Dadgar, A.; Schulze, F.; Günther, M.; Witte, H.; BlÄsing, J.; Krost, A.; daumiller, I.; et al. Unstrained InAIN/GaN HEMT structure. Int. J. High Speed Electron. Syst. 2004, 14, 785-790. [CrossRef]

11. Ge, M.; Cai, Q.; Zhang, B.H.; Chen, D.J.; Hu, L.Q.; Xue, J.J.; Lu, H.; Zhang, R.; Zheng, Y.D. Effects of the trap level in the unintentionally doped GaN buffer layer on optimized p-GaN gate AlGaN/GaN HEMTs. Phys. Status Solidi A 2018, 215, 1700368. [CrossRef]

12. Kuzmík, J.; Kostopoulos, A.; Konstantinidis, G.; Carlin, J.F.; Georgakilas, A.; Pogany, D. InAlN/GaN HEMTs: A first insight into technological optimization. IEEE Trans. Electron Devices 2006, 53, 422-426. [CrossRef]

13. Kuzmík, J. InAlN/(In) GaN high electron mobility transistors: Some aspects of the quantum well heterostructure proposal. Semicond. Sci. Technol. 2002, 17, 540-544. [CrossRef]

14. Medjdoub, F.; Carlin, J.F.; Gaquière, C.; Grandjean, N.; Kohn, E. Status of the emerging InAlN/GaN power HEMT technology. Open Electr. Electron. Eng. J. 2008, 2, 1-7. [CrossRef]

15. Shrestha, N.M.; Li, Y.; Chang, E.Y. Simulation study on electrical characteristic of AlGaN/GaN high electron mobility transistors with AlN spacer layer. Jpn. J. Appl. Phys. 2014, 53, 04EF08. [CrossRef]

16. Teke, A.; Gokden, S.; Tulek, R.; Leach, J.H.; Fan, Q.; Xie, J.; Ozgur, U.; Morkoc, H.; Lisesivdin, S.B.; Ozbay, E. The effect of AlN interlayer thicknesses on scattering processes in lattice-matched AlInN/GaN two-dimensional electron gas heterostructures. New J. Phys. 2009, 11, 063031. [CrossRef]

17. Khan, M.A.; Kuznia, J.N.; Van Hove, J.M.; Pan, N.; Carter, J. Observation of a two-dimensional electron gas in low pressure metalorganic chemical vapor deposited $\mathrm{GaN}_{-} \mathrm{Al}_{\mathrm{x}} \mathrm{Ga}_{1-\mathrm{x}} \mathrm{N}$ heterojunctions. Appl. Phys. Lett. 1992, 60, 3027-3029. [CrossRef]

18. Imanaga, S.; Kawai, H. Novel AlN/GaN insulated gate heterostructure field effect transistor with modulation doping and one-dimensional simulation of charge control. J. Appl. Phys. 1997, 82, 5843-5858. [CrossRef]

19. Chen, C.Q.; Zhang, J.P.; Adivarahan, V.; Koudymov, A.; Fatima, H.; Simin, G. AlGaN/GaN/AlGaN double heterostructure for high-power III-N field-effect transistors. Appl. Phys. Lett. 2003, 82, 4593. [CrossRef]

20. Lee, D.S.; Gao, X.; Guo, S. InAlN/GaN HEMTs with AlGaN back barriers. IEEE Electron Devcies Lett. 2011, 32, 617-619. [CrossRef]

21. Meng, F.; Zhang, J.; Zhou, H. Transport characteristics of AlGaN/GaN/AlGaN double heterostructures with high electron mobility. J. Appl. Phys. 2012, 112, 023707. [CrossRef]

22. Yao, C.J.; Yang, G.F.; Li, Y.J.; Sun, R.; Zhang, Q.; Wang, J.; Gao, S.M. Investigation of N-face AlGaN ultraviolet light-emitting diodes with composition-varying AlGaN electron blocking layer. Opt. Quant. Electron. 2016, 48, 31. [CrossRef]

23. Yao, C.J.; Ye, X.C.; Sun, R.; Yang, G.F.; Wang, J.; Lu, Y.N.; Yan, P.F.; Cao, J.T.; Gao, S.M. High-performance AlGaN-based solar-blind avalanche photodiodes with dual-periodic III-nitride distributed Bragg reflectors. Appl. Phys. Express 2017, 10, 034302. [CrossRef]

24. Wang, H.; Jiang, L.L.; Wang, N.; Yu, H.Y.; Lin, X.P. A Charge Storage Based Enhancement Mode AlGaN/GaN High Electron Mobility Transistor. Mater. Sci. Forum 2018, 913, 870-875. [CrossRef]

25. Della Corte, F.G.; Pezzimenti, F.; Bellone, S.; Nipoti, R. Numerical simulations of a 4H-SiC BMFET power transistor with normally-off characteristics. Mater. Sci. Forum 2011, 679-680, 621-624. [CrossRef]

26. Anvarifard, M.K.; Orouji, A.A. Proper Electrostatic Modulation of Electric Field in a Reliable Nano-SOI With a Developed Channel. IEEE Trans. Electron Devices 2018, 65, 1653-1657. [CrossRef]

27. Pezzimenti, F. Modeling of the steady state and switching characteristics of a normally-off $4 \mathrm{H}-\mathrm{SiC}$ trench bipolar-mode FET. IEEE Trans. Electron Devices 2013, 60, 1404-1411. [CrossRef] 
28. Della Corte, F.G.; de Martino, G.; Pezzimenti, F.; Adinolfi, G.; Graditi, G. Numerical simulation study of a low breakdown voltage $4 \mathrm{H}-\mathrm{SiC}$ MOSFET for photovoltaic module-level applications. IEEE Trans. Electron Devices 2018, 65, 3352-3360. [CrossRef]

29. Wang, Y.; Li, Z.Y.; Hao, Y.; Luo, X.; Fang, J.P.; Ma, Y.C.; Yu, H.Y.; Cao, F. Evaluation by Simulation of AlGaN/GaN Schottky Barrier Diode (SBD) With Anode-Via Vertical Field Plate Structure. IEEE Trans. Electron Devices 2018, 65, 2552-2557. [CrossRef]

30. Faramehr, S.; Kalna, K.; Igić, P. Modeling of 2DEG and 2DHG in i-GaN capped AlGaN/AlN/GaN HEMTs. In Proceedings of the International Conference on Microelectronics, Belgrade, Serbia, 12-14 May 2014; pp. 81-84.

31. Ochiai, M.; Akita, M.; Ohno, Y.; Kishimoto, S.; Maezawa, K.; Mizutani, T. AlGaN/GaN heterostructure metal-insulator-semiconductor high-electron-mobility transistors with Si3N4 gate insulator. Jap. J. Appl. Phys. 2003, 42, 2278-2280. [CrossRef]

32. Han, T.; Zhao, H.; Peng, X.; Li, Y. Control of short-channel effects in InAlN/GaN high-electron mobility transistors using graded AlGaN buffer. Superlattice Microst. 2018, 116, 207-214. [CrossRef]

33. MorkoC, H.; Cingolani, R.; Gil, B. Polarization effects in nitride semiconductor device structures and performance of modulation doped field effect transistors. Solid-State Electron. 1999, 43, 1909-1927. [CrossRef]

34. Ambacher, O.; Smart, J.; Shealy, J.R.; Weimann, N.G.; Chu, K.; Murphy, M.; Schaff, W.J.; Eastman, L.F.; Dimitrov, R.; Wittmer, L.; et al. Two-dimensional electron gases induced by spontaneous and piezoelectric polarization charges in N- and Ga-face AlGaN/GaN heterostructures. J. Appl. Phys. 1999, 87, 3222-3233. [CrossRef]

35. Ambacher, O.; Majewski, J.; Miskys, C.; Link, A.; Hermann, M.; Eickhoff, M.; Stutzmann, M.; Bernardini, F.; Fiorentini, V.; Tilak, V.; et al. Pyroelectric properties of $\mathrm{Al}$ (In) GaN/GaN hetero-and quantum well structures. J. Phys. Condens. Matter 2002, 14, 3399-3434. [CrossRef]

36. Pelá, R.R.; Caetano, C.; Ferreira, L.G.; Furthmüller, J.; Teles, L.K. Accurate band gaps of AlGaN, InGaN, and AlInN alloys calculations based on LDA-1/2 approach. Appl. Phys. Lett. 2011, 98, 151907. [CrossRef]

37. Goswami, A.; Trew, R.J.; Bilbro, G.L. Physics of gate leakage current in N-polar InAlN/GaN heterojunction field effect transistors. J. Appl. Phys. 2014, 116, 164508. [CrossRef]

38. SILVACO Int. ATLAS User's Manual; Device Simulation Software: Santa Clara, CA, USA, 2016; Available online: https://www.silvaco.com (accessed on 1 February 2013).

39. Hall, R.N. Electron-hole recombination in germanium. Phys. Rev. 1952, 87, 387. [CrossRef]

40. Shockley, W. Statistics of the recombinations of holes and electrons. Phys. Rev. 1952, 87, 835-842. [CrossRef]

41. Megherbi, M.L.; Pezzimenti, F.; Dehimi, L.; Saadoune, M.A.; Della Corte, F.G. Analysis of trapping effects on the forward current-voltage characteristics of al-implanted $4 \mathrm{H}-\mathrm{SiC}$-i-n Diodes. IEEE Trans. Electron Devices 2018, 65, 3371-3378. [CrossRef]

42. Inoue, T.; Nakayama, T.; Ando, Y.; Kosaki, M.; Miwa, H.; Hirata, K.; Uemura, T.; Miyamoto, H. Polarization engineering on buffer layer in GaN-based heterojunction FETs. IEEE Trans. Electron. Devices 2008, 55, 483-488. [CrossRef]

43. Li, C.; Li, Z.; Peng, D.; Ni, J.; Pan, L.; Zhang, D. Improvement of breakdown and current collapse characteristics of GaN HEMT with a polarization-graded AlGaN buffer. Semicond. Sci. Technol. 2015, 30, 035007. [CrossRef] 